\title{
Interleukin (IL)-1 $\beta$ in Tracheal Aspirates from Premature Infants Induces Airway Epithelial Cell IL-8 Expression via an NF- $\kappa$ B Dependent Pathway
}

\author{
THOMAS K. SHIMOTAKE, FARZANA M. IZHAR, KANDELARIA RUMILLA, JING LI, ALAN TAN, \\ KRISTEN PAGE, ALLAN R. BRASIER, MICHAEL D. SCHREIBER, AND MARC B. HERSHENSON \\ Department of Pediatrics [T.K.S., F.M.I., K.R., J.L., A.T., K.P., M.D.S., M.B.H.], University of Chicago, \\ Chicago, Illinois 60637, Department of Medicine [A.R.B.], The University of Texas Medical Branch, \\ Galveston, Texas 77555
}

\begin{abstract}
ABSTR
Tracheal aspirate IL- 8 concentration and airway epithelial
cell IL- 8 expression are each increased in premature infants
undergoing mechanical ventilation. We sought to determine the
cytokines responsible for IL- 8 expression in this context. Tra-
cheal aspirates were collected from 18 mechanically ventilated
premature infants. IL- 8 protein abundance was high in tracheal
aspirates from ventilated premature infants (mean, $5806 \pm 4923$
pg/mL). IL- $\alpha$ (mean, $20 \pm 6$ pg/mL), IL- $1 \beta$ (mean $67 \pm 46$
pg/mL), and tumor necrosis factor (TNF)- $\alpha$ (mean, $8 \pm 2$ pg/mL)
were also found. Incubation of tracheal aspirates with
$16 H B E 140-$ human bronchial epithelial cells increased IL- 8 pro-
tein in both cell lysates and supernatants, as well as transcription
from the IL- 8 promoter. Aspirates also induced nuclear factor
(NF)- $\kappa \mathrm{B}$ activation. Mutation of the IL- 8 promoter NF- $\kappa \mathrm{B}$ site
abolished aspirate-induced IL- 8 transcription. Endotoxin concen-
trations in the tracheal aspirates were negligible and incapable of
\end{abstract}
Despite advances in neonatal care, BPD continues to be a major cause of morbidity and mortality in premature neonates. Accordingly, interest remains high in the pathogenesis of this chronic lung disease. Recent evidence suggests the importance of inflammation in the pathogenesis of BPD. During the first days of postnatal life, an influx of polymorphonuclear leukocytes and macrophages is seen in the tracheal aspirates of mechanically ventilated premature infants who later develop BPD (1). Elevations of pro-inflammatory cytokines such as IL-8, IL-6, IL-1 $\beta$, and TNF- $\alpha$ are also seen (2-7). Similar findings are present in animal models of BPD (8) and hyper-

Received November 18, 2002; accepted July 15, 2003.

Correspondence: Marc B. Hershenson, M.D., University of Michigan, 1500 East Medical Center Dr., Women's Hospital L2211, Box 0212, Ann Arbor, MI 48109-0212; e-mail: mhershen@umich.edu

Supported by National Institutes of Health Grant HL56399 and the Children's Research Foundation.

DOI: 10.1203/01.PDR.0000145274.47221.10 inducing IL-8 promoter activity. Finally, incubation of tracheal aspirates with a neutralizing antibody against IL- $1 \beta$ reduced epithelial cell IL-8 production, whereas neutralizing antibodies against IL- $1 \alpha$ and TNF- $\alpha$ had no effect. We conclude that airway fluid from mechanically ventilated premature infants contains soluble factors capable of inducing airway epithelial cell IL-8 expression via a NF- $\kappa \mathrm{B}$-dependent pathway, and that IL-1 $\beta$ plays a specific role in this process. (Pediatr Res 56: 907-913, 2004)
AP-1, activator protein-1
BPD, bronchopulmonary dysplasia
$\mathbf{N F}-\boldsymbol{\kappa} \mathbf{B}$, nuclear factor $-\kappa \mathrm{B}$
TNF- $\alpha$, tumor necrosis factor- $\alpha$

Abbreviation oxic exposure (9). Of the cytokines implicated in BPD, IL-8 may be of special importance, as it is the most potent neutrophil chemotactic factor.

IL-8 may be elaborated by macrophages, T-lymphocytes, neutrophils, and respiratory epithelial cells (4). In a recent study examining IL-8 expression in the lung tissue of neonates with hyaline membrane disease, the majority of cases demonstrated IL-8 immunoreactivity in fetal and neonatal neutrophils, and in almost half of these cases, airway epithelial cell IL-8 expression (10). An earlier study in ventilated preterm infants detected IL-8 in bronchoalveolar macrophages, neutrophils, and exfoliated epithelial cells (6). In newborn rats, hyperoxic exposure induced the expression of cytokineinduced neutrophil chemoattractant-1, an IL-8 homologue, in alveolar macrophages and epithelial cells (9). Numerous studies have shown that cultured airway epithelial cells may produce IL-8 in response to a variety of stimuli (11-14). We therefore tested the hypothesis that there are factors in the 
tracheal aspirates of mechanically ventilated premature infants capable of eliciting IL-8 expression in cultured airway epithelial cells. Further, using ELISA and neutralizing antibody experiments, we attempted to identify the substance(s) responsible for the observed IL-8 production. Finally, we examined the role of $\mathrm{NF}-\kappa \mathrm{B}$ in this process.

\section{METHODS}

Tracheal aspirate collection. Aspirates were collected during routine tracheal suctioning of mechanically ventilated newborns (15). Infants were positioned in a supine posture with head midline. One milliliter of sterile nonbacteriostatic saline was instilled into the endotracheal tube, four breaths delivered, and the airway suctioned with a sterile catheter into a Leuken's trap. This procedure was repeated before the catheter was flushed with $1 \mathrm{~mL}$ saline and placed on ice. Specimens were centrifuged $\left(13,000 \mathrm{rpm}\right.$ for $4 \mathrm{~min}$ at $\left.4^{\circ} \mathrm{C}\right)$ and supernatants stored at $-80^{\circ} \mathrm{C}$ within $1 \mathrm{~h}$ of collection. This study was approved by the University of Chicago Institutional Review Board.

Patients. Tracheal aspirates were collected from a total of 18 premature infants. All study infants were premature (gestational age at birth $<32 \mathrm{wk}$ ), mechanically ventilated for respiratory distress, and $\leq 14 \mathrm{~d}$ of age. The average gestational age was $26.9 \pm 0.6 \mathrm{wk}$ (mean \pm SEM). The average day of life was $5.7 \pm 1.1 \mathrm{~d}$. The average birth weight was $971 \pm 98 \mathrm{~g}$. Due to the small volume of tracheal aspirate collected from any single infant $(<2 \mathrm{~mL})$, samples from the same patients could not be used for all experiments. However, aspirates from the same eight patients were used for analyses of tracheal aspirate cytokine concentration, tracheal aspirate-induced IL-8 protein secretion, and neutralizing antibody experiments. Infants were excluded if there was evidence of acute sepsis or postnatal exposure to systemic glucocorticoid therapy. For comparison, aspirates were also collected from two fullterm newborns without respiratory disease who were intubated for surgical procedures (gestational ages at birth, 39 and $40 \mathrm{wks}$; days of life, 2 and 13 d; birth weights, 2975 and $3080 \mathrm{~g}$ ).

Cell culture. A derivative of 16HBE140- human bronchial epithelial cells, provided by S. White (University of Chicago), was studied (16). The line was originally established from human bronchial epithelial tissue by transfection with pSVori-, which contains the origin-defective SV40 genome (17). Unlike the parental line, cells do not grow in distinct clusters and demonstrate improved transfection efficiency. Cultures show specific immunostaining with pan-cytokeratin, bind galactose, or galactosamine-specific lectins particular to basal epithelial cells (18) and express $\beta 1-, \alpha 2-, \alpha 3-$, and $\alpha 6$-integrin subunits on their cell surface (19). Cells were grown on coated plates (fibronectin, $10 \mu \mathrm{g} / \mathrm{mL}$; collagen, $30 \mu \mathrm{g} / \mathrm{mL}$; BSA, $100 \mu \mathrm{g} /$ $\mathrm{mL}$ ) in minimum essential medium (MEM) with $10 \%$ fetal bovine serum (FBS), 1\% penicillin-streptomycin, and $200 \mathrm{mM}$ of L-glutamine. Incubation was at $37^{\circ} \mathrm{C}$ and $5 \% \mathrm{CO}_{2}$.

Measurement of $I L-8, I L-1 \alpha, I L-1 \beta$, and $T N F-\alpha$ protein abundance. IL- 8 , IL- $1 \alpha$, IL- $1 \beta$, or TNF- $\alpha$ protein abundance was measured by ELISA (Endogen Corporation, Woburn, MA). Measurements from tracheal aspirates and cell superna- tants were straightforward. To determine intracellular IL-8 concentration, cells were lysed in homogenization buffer (20) and lysates collected and centrifuged to remove debris before assay.

Transient transfection of human airway epithelial cells. The $-162 /+44$ fragment of the human IL- 8 promoter was subcloned into a luciferase reporter $(-162 /+44$ hIL-8/Luc) $(11,21)$. Mutations of the NF- $\kappa \mathrm{B}$ and AP-1 sites in the context of $-162 /+44 \mathrm{hIL}-8 / \mathrm{Luc}$ were introduced by polymerase chain reaction with mutagenic primers to obtain $\Delta \mathrm{NF}-\kappa \mathrm{B} 162 /+44$ hIL-8/Luc and $\Delta$ AP-1 162/+44 hIL-8/Luc (11). NF- $\kappa$ B -TATA/luc was purchased from Stratagene (La Jolla, CA). Cells were co-transfected with pCMV-LacZ (provided by M. Rosner, University of Chicago) to normalize for transfection efficiency. Cells were transfected using Lipofectamine (Invitrogen, Carlsbad, CA) (20). Approximately $0.5 \mu \mathrm{g}$ total plasmid DNA per $35 \mathrm{~mm}$ dish was used. After treatment, cells were harvested for analysis of luciferase activity using lysis buffer provided with the Promega Luciferase Assay system (Madison, WI). Luciferase activity was measured at room temperature using a luminometer (Turner Designs, Sunnyvale, CA). $\beta$-galactosidase activity was assessed by colorimetric assay using o-nitrophenyl- $\beta$-D-galactoside as a substrate (22).

Electrophoretic mobility shift assays. Nuclear extracts were prepared by the method of Dignam et al. (23) with modifications, and electrophoretic mobility shift assays performed as described (24). In some instances, antibodies against either p65 RelA, an NF- $\kappa \mathrm{B}$ family binding protein, Jun, or Fos were added (10 min at room temperature; Santa Cruz Biotechnology, Santa Cruz, CA). An oligonucleotide probe encoding the $\mathrm{NF}-\kappa \mathrm{B}$ consensus sequence was purchased from Promega (Madison, WI).

Measurement of endotoxin levels. Tracheal aspirate endotoxin concentration was measured by Limulus Amebocyte Lysate assay (BioWhittaker, Walkersville, MD).

IL-8 response to tracheal aspirates. After serum starvation ( $8 \mathrm{~h}$ for transfection experiments, $24 \mathrm{~h}$ for all others), cells were treated with tracheal aspirates (1:10 dilution with MEM). Selected cultures were treated with TNF- $\alpha$ (R \& D Systems, Minneapolis, MN) IL- $1 \alpha$ or IL- $1 \beta$ (Calbiochem, La Jolla, CA). Cells were then incubated overnight $(16 \mathrm{~h})$ at $37^{\circ} \mathrm{C}$ and $5 \%$ $\mathrm{CO}_{2}$. Cell lysates and supernatants were then analyzed for IL-8 protein abundance or luciferase activity, as described above. In selected experiments, tracheal aspirates were preincubated with monoclonal rabbit anti-human IL- $1 \alpha(5 \mu \mathrm{g} / \mathrm{mL}, 1 \mathrm{~h}$ at 24 $\left.\mathrm{C}^{\circ}\right)$, IL-1 $\beta$ (5 $\left.\mu \mathrm{g} / \mathrm{mL}\right)$, or TNF- $\alpha$ neutralizing antibody (1.2 $\mu \mathrm{g} / \mathrm{mL}$; all antibodies from Endogen, Woburn, MA) or rabbit IgG control ( $5 \mu \mathrm{g} / \mathrm{mL}$; Jackson ImmunoResearch, West Grove, PA). Antibody concentrations were selected by measuring bronchial epithelial cell IL-8 expression in response to various doses of cytokines and determining the minimum concentration of antibody needed to block the maximal observed IL-8 response. After treatment with tracheal aspirates or TNF- $\alpha$ as described above, IL-8 secretion was determined by ELISA. To determine whether neutralizing antibodies interfere with the IL-8 ELISA, neutralizing antibodies against IL- $1 \alpha$, IL-1 $\beta$ (5 $\mu \mathrm{g} / \mathrm{mL})$, and TNF- $\alpha(1.2 \mu \mathrm{g} / \mathrm{mL})$ were preincubated with recombinant IL-8 protein at $100 \mathrm{pg} / \mathrm{mL}, 1000 \mathrm{pg} / \mathrm{mL}$, and 2500 
$\mathrm{pg} / \mathrm{mL}$ concentrations, and OD readings determined by ELISA. Preincubation with neutralizing antibodies did not appreciably reduce the OD of standard IL-8 samples (data not shown).

Data analysis. Each experiment was performed at least three times (i.e. with samples from at least three separate individuals). Data were described as the mean \pm SEM. For reporter assays, changes in promoter activity were calculated as arbitrary light units/ $\beta$-galactosidase calorimetric units/h. The significance of changes in luciferase activity and protein abundance was assessed by paired $t$ test or one-way ANOVA with repeated measures. Differences identified by ANOVA were pinpointed by Student-Newman-Keuls multiple range test.

\section{RESULTS}

Tracheal aspirate $I L-8, I L-1 \alpha, I L-1 \beta$, and $T N F-\alpha$ protein abundance. We measured tracheal aspirate IL-8, IL-1 $\alpha$, IL-1 $\beta$, and TNF- $\alpha$ protein abundance by ELISA. Consistent with previous reports $(3,5,7)$, IL-8 protein levels were high (5806 $\pm 4923 \mathrm{pg} / \mathrm{mL}, n=8$ for each cytokine), whereas concentrations of IL-1 $\alpha(20 \pm 6 \mathrm{pg} / \mathrm{mL}), \mathrm{IL}-1 \beta(67 \pm 46 \mathrm{pg} / \mathrm{mL})$, and TNF- $\alpha(8 \pm 2 \mathrm{pg} / \mathrm{mL})$ in the tracheal aspirates were relatively modest.

Tracheal aspirates from mechanically ventilated premature infants increase IL-8 expression in cultured airway epithelial cells. 16HBE14o- cells were serum starved for $24 \mathrm{~h}$ and incubated with tracheal aspirates (1:10 dilution) overnight. Incubation of cell cultures with tracheal aspirates from premature infants with respiratory disease increased intracellular IL-8 protein approximately 3 -fold (unstimulated, $78 \pm 36 \mathrm{pg} / \mathrm{mL}$; tracheal aspirates, $213 \pm 40 \mathrm{pg} / \mathrm{mL} ; n=5 ; p=0.028$, paired $t$ test; Fig. $1 a$ ).

To determine whether tracheal aspirate-induced IL-8 protein expression is transcriptionally regulated, cells were transiently transfected with the $-162 /+44 \mathrm{hIL}-8 / \mathrm{Luc}$ reporter plasmid and incubated with tracheal aspirates (1:10 dilution). Tracheal aspirates significantly increased transcription from the IL-8 promoter (fold increase, $4.07 \pm 0.97 ; n=9 ; p=0.005$; paired $t$ test; Fig. $1 b$ ), consistent with the notion that airway epithelial cells are a source of airway fluid IL-8. Tracheal aspirates from two newborn full-term infants without respiratory disease had no significant effect on IL-8 promoter activity (mean fold increase, 1.38).

Endotoxin levels in tracheal aspirates. Endotoxin has been reported to increase IL-8 expression in airway epithelial cells $(25,26)$. Endotoxin concentrations of tracheal aspirates from three premature infants with respiratory disease were measured by Limulus Amebocyte Lysate assay. The mean endotoxin concentration was $2.33 \mathrm{EU} / \mathrm{mL}$, equivalent to $0.23 \mathrm{ng} / \mathrm{mL}$ of lipopolysaccharide (LPS). To test whether endotoxin in tracheal aspirates could be responsible for the observed transcription from the IL-8 promoter, cells were transiently transfected with the IL-8 reporter plasmid and then incubated with Escherichia coli endotoxin (BioWhittaker). Concentrations of endotoxin up to $1 \mu \mathrm{g} / \mathrm{mL}$ failed to increase IL-8 promoter activity, whereas as incubation of cells with TNF- $\alpha(10 \mathrm{ng} / \mathrm{mL})$ increased transcription more than 10 -fold. Together, these data
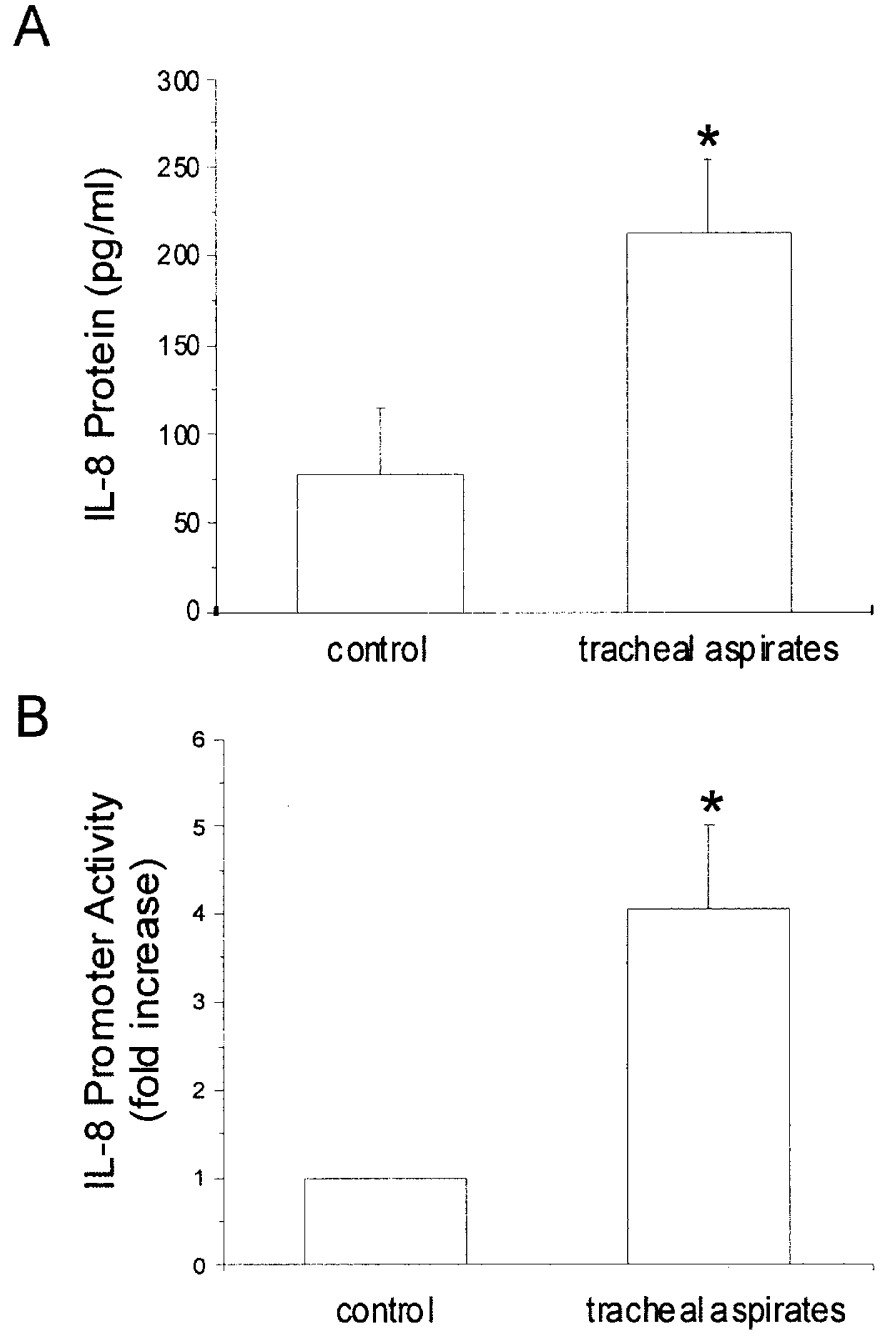

Figure 1. (A) Tracheal aspirates from mechanically ventilated premature infants with respiratory disease increase cultured airway epithelial cell IL-8 protein abundance. Intracellular IL- 8 protein was measured by ELISA $(n=5$, $* p=0.028)$. (B) Tracheal aspirates from mechanically ventilated premature infants with respiratory disease increase transcription from the IL-8 promoter in cultured airway epithelial cells. Cells were transfected with $-162 /+44$ hIL-8/Luc, serum starved, and incubated with tracheal aspirates $(n=9)$ for $16 \mathrm{~h}$. Luciferase and $\beta$-galactosidase activities were measured with a luminometer and by colorimetric assay, respectively $\left({ }^{*} p=0.005\right)$.

suggest that endotoxin is not responsible for tracheal aspiratemediated increments in IL-8 expression.

Effect of cytokines and tracheal aspirates on airway epithelial cell IL-8 secretion. We tested whether IL- $1 \alpha$, IL- $1 \beta$, or TNF- $\alpha$ were responsible for tracheal aspirate-induced IL-8 expression in airway epithelial cells. First, in pilot studies, we examined whether the concentrations of these cytokines found in tracheal aspirates could induce airway epithelial cell IL-8 expression. Serum-starved 16HBE14o- cells were incubated overnight $(16 \mathrm{~h})$ with known concentrations of cytokines. Supernatant IL-8 levels were measured by ELISA. Concentration-response studies (Fig. 2) showed that $10 \mathrm{pg} / \mathrm{mL} \mathrm{IL-1} \alpha$ increased IL-8 protein secretion from 43 to $239 \mathrm{pg} / \mathrm{mL}$, and 30 $\mathrm{pg} / \mathrm{mL}$ IL- $1 \alpha$ increased IL- 8 protein secretion to $889 \mathrm{pg} / \mathrm{mL}$, consistent with the notion that levels of IL- $1 \alpha$ present in the tracheal aspirate (mean, $20 \mathrm{pg} / \mathrm{mL}$ ) could be responsible for the 


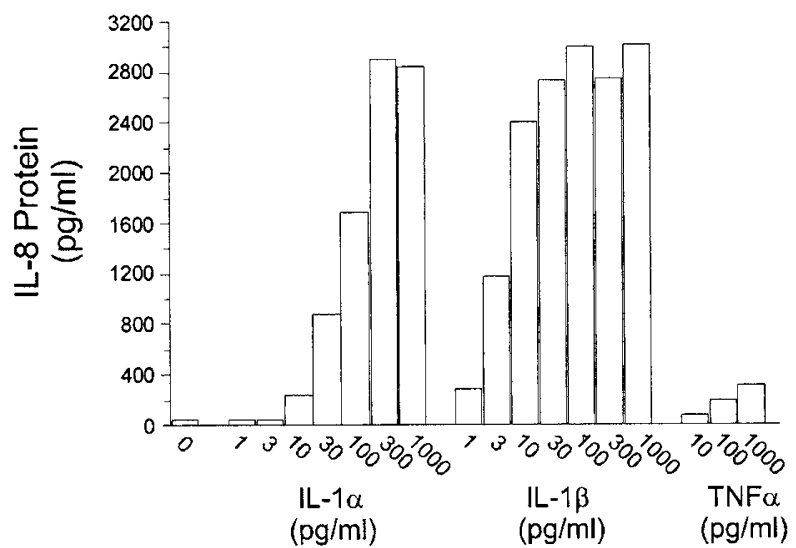

Figure 2. IL- $1 \alpha$, IL- $1 \beta$, and TNF- $\alpha$ concentration response curves for airway epithelial cell IL- 8 protein secretion. IL- $1 \beta$ was the most potent activator of airway IL- 8 expression, followed by IL- $1 \alpha$ and TNF- $\alpha$.

observed IL-8 expression. Pilot studies showed a more vigorous response to IL- $1 \beta$, with $30 \mathrm{pg} / \mathrm{mL}$ increasing IL- 8 protein secretion to $2737 \mathrm{pg} / \mathrm{mL}$ (mean IL- $\beta$ concentration in tracheal aspirate, $67 \mathrm{pg} / \mathrm{mL}$ ). Finally, $10 \mathrm{pg} / \mathrm{mL}$ TNF- $\alpha$ increased IL-8 expression only to $72 \mathrm{pg} / \mathrm{mL}$ (mean TNF- $\alpha$ concentration in tracheal aspirate, $8 \mathrm{pg} / \mathrm{mL}$ ). Together, these data suggest that concentrations of IL- $1 \beta$ and IL- $1 \alpha$ (but not TNF- $\alpha$ ) in the tracheal aspirates of premature infants undergoing mechanical ventilation for respiratory distress within the first $2 \mathrm{wk}$ of life are capable of inducing the level of airway epithelial cell IL-8 expression observed.

Second, we examined the effect of neutralizing antibodies on tracheal aspirate-induced airway epithelial cell IL-8 secretion. Tracheal aspirates from mechanically ventilated premature infants (1:10 dilution) increased supernatant (extracellular) IL-8 protein abundance from $21 \pm 1$ to $2052 \pm 714 \mathrm{pg} / \mathrm{mL}(n$ $=8$, Fig. 3). This response was substantially more vigorous than the change in intracellular IL-8 (Fig. 1a), suggesting that most of the induced IL-8 protein was secreted. Given the 1:10 dilution of tracheal aspirates, this increase in extracellular IL-8 protein cannot be accounted for by IL-8 in the tracheal aspi-

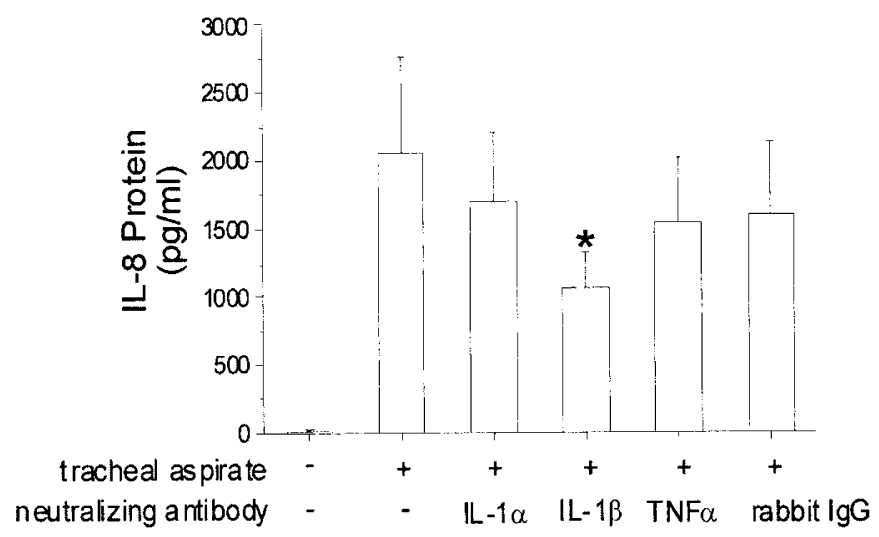

Figure 3. Rabbit anti-human IL-1 $\beta$ neutralizing antibody inhibits tracheal aspirate-induced IL-8 protein secretion. Tracheal aspirates $(n=8)$ were preincubated with anti-IL- $1 \beta$, IL- $1 \alpha$, or TNF- $\alpha$ before treatment of airway epithelial cells (1:10 dilution). Neutralizing antibody significantly attenuated extracellular IL-8. Incubation with anti-IL- $1 \alpha$, anti-TNF- $\alpha$, or rabbit IgG did not attenuate tracheal aspirate-induced responses $* p<0.05$, ANOVA). rates alone. We therefore examined the effects of neutralizing antibody on extracellular, rather than intracellular, IL-8 protein abundance. Preincubation with rabbit anti-human neutralizing antibody to IL- $1 \beta$, but not neutralizing antibody to IL- $1 \alpha$ or TNF- $\alpha$, significantly reduced tracheal aspirate-induced IL- 8 protein abundance $(p<0.03$, ANOVA). Rabbit IgG had no significant effect. These data suggest that IL- $1 \beta$, but not IL- $1 \alpha$ or TNF- $\alpha$, is in part responsible for the observed increase in IL-8 expression.

Tracheal aspirates increase $\mathrm{NF}-\mathrm{\kappa} B$ protein binding to $D N A$ and $N F-\kappa B$ transactivation. To test whether tracheal aspirates induce the binding of NF- $\kappa$ B to DNA, we obtained nuclear extracts from airway epithelial cell cultures exposed to tracheal aspirates from three individual premature infants with respiratory disease. Nuclear extracts were then incubated with $[\gamma-32 \mathrm{P}]-\mathrm{ATP}$ labeled oligonucleotide encoding the consensus $\mathrm{NF}-\kappa \mathrm{B}$ binding site. Incubation of airway epithelial cells with tracheal aspirates induced significant NF- $\kappa \mathrm{B}$ DNA binding (Fig. 4a). Co-incubation of nuclear extracts with an antibody against p65 RelA, but not Jun or Fos, induced supershift of the DNA binding complex, demonstrating the presence of p65 (Fig. 4b).

To confirm that NF- $\kappa \mathrm{B}$ binding results in transactivation, 16HBE140- cells were transfected with a NF- $\kappa$ B reporter plasmid and exposed to tracheal aspirates from premature infants with respiratory disease. IL- $1 \beta$ treatment $(0.1 \mathrm{ng} / \mathrm{mL}$ for $16 \mathrm{~h}$ ) was used as a positive control. Aspirates induced significant NF- $\kappa \mathrm{B}$ transactivation (Fig. 5). Incubation of $16 \mathrm{HBE} 14 \mathrm{o}-$ cells with $0.1 \mathrm{ng} / \mathrm{mL}$ IL- $1 \beta$ also increased NF- $\kappa \mathrm{B}$ transactivation.

Effects of $\mathrm{NF}-\kappa \mathrm{B}$ and AP-1 mutations on tracheal aspirate-induced transcription from the IL-8 promoter. To examine the role of the NF- $\kappa \mathrm{B}$ transcription factor complex in the induction of IL-8 expression, cells were transfected with cDNAs encoding IL-8 promoter constructs with mutations of either the NF- $\kappa \mathrm{B}$ or AP-1 binding sites. Mutation of the NF- $\kappa \mathrm{B}$ site abolished the IL- 8 promoter responsiveness to tracheal

A

B

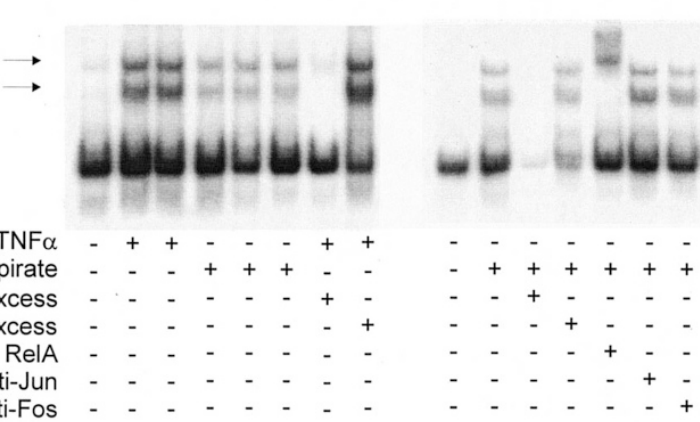

Figure 4. (A) Tracheal aspirates increase NF- $\kappa$ B protein binding to DNA. Nuclear extracts were incubated with labeled NF- $\kappa \mathrm{B}$ oligonucleotide and resolved by electrophoresis through a polyacrylamide gel. Tracheal aspirates from three separate individuals induced the binding of two NF- $\kappa \mathrm{B}$ proteins (arrows). Binding was abolished with cold excess NF- $\kappa \mathrm{B}$, but not AP-2 probe. For comparison, the response to TNF- $\alpha(5 \mathrm{ng} / \mathrm{mL})$ is shown. (B) Incubation with anti-p65 RelA induced supershift of both NF- $\kappa$ B DNA binding complexes. 


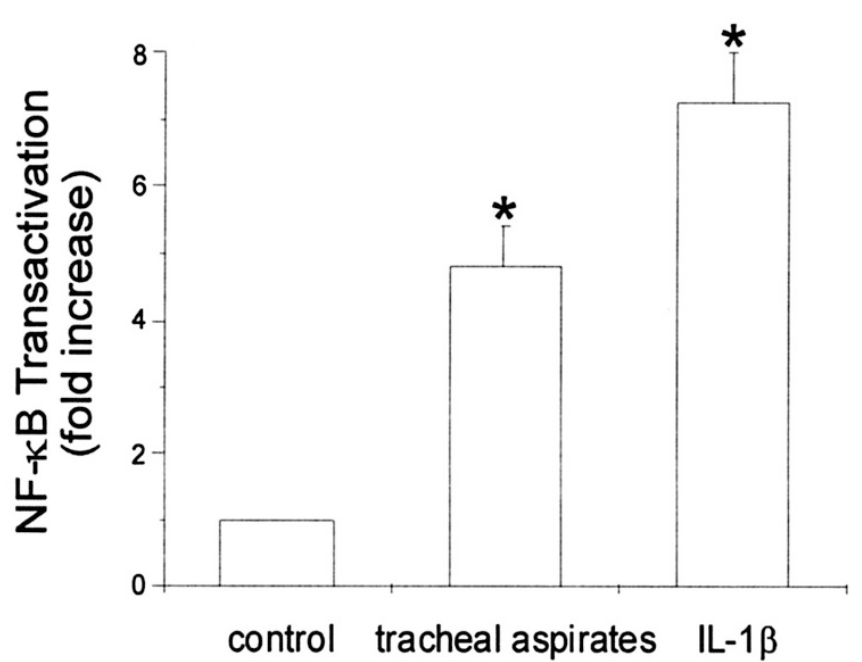

Figure 5. Tracheal aspirates and IL- $1 \beta$ each increase NF- $\kappa$ B transactivation. Cells were transfected with an NF- $\kappa \mathrm{B}$ reporter plasmid, serum starved, and incubated with tracheal aspirates for $16 \mathrm{~h}$. Selected cultures were treated with $0.1 \mathrm{ng} / \mathrm{mL}$ IL-1 $\beta$ ( $n=11$, *different from control, $p<0.05$, ANOVA).

aspirates, whereas mutation of the AP-1 site had little effect, i.e. there was still a significant increase in response to tracheal aspirates $(n=4, p<0.05$, ANOVA; Fig. 6). On the other hand, mutation of the AP-1 site decreased both basal and tracheal aspirate-induced promoter activity, suggesting that this site functions as a basal level enhancer. Together, these data suggest that NF- $\kappa \mathrm{B}$ transactivation is required for tracheal aspirate-induced transcription from the IL-8 promoter.

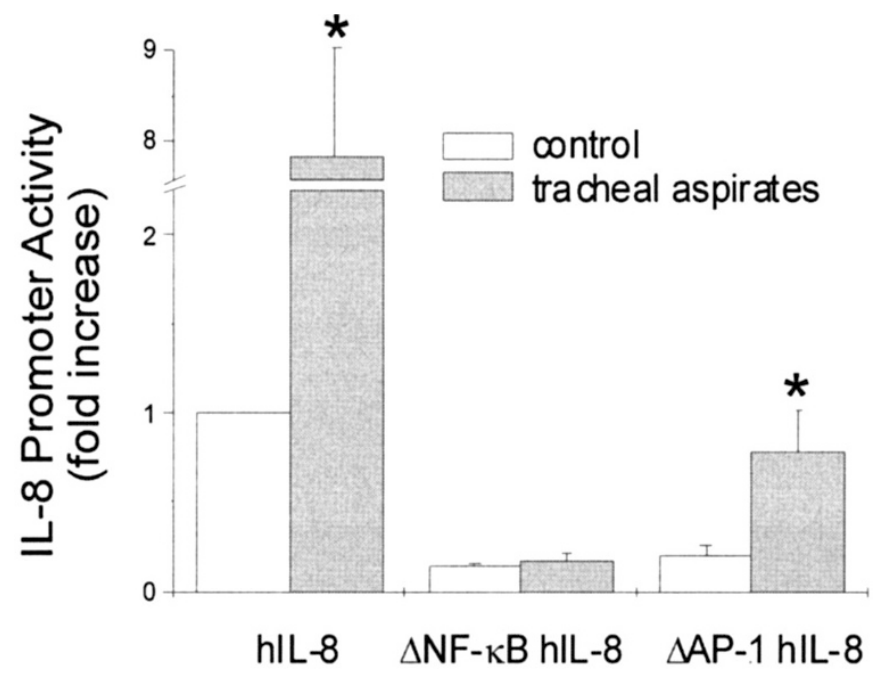

Figure 6. Effects of NF- $\kappa \mathrm{B}$ and AP-1 mutations on tracheal aspirate-induced transcription from the IL-8 promoter. Cells were transfected with $\Delta$ NF- $\kappa \mathrm{B}$ $162 /+44 \mathrm{hIL}-8 / \mathrm{Luc}$ or $\Delta \mathrm{AP}-1162 /+44 \mathrm{hIL}-8 / \mathrm{Luc}$, serum starved, and incubated with tracheal aspirates $(n=4)$ for $16 \mathrm{~h}$. Data are shown as fold increase relative to control for the full-length promoter. Mutation of the NF- $\kappa \mathrm{B}$ site abolished the response to tracheal aspirates, whereas IL- 8 promoter activity still increased significantly after mutation of the AP-1 site (*different from unstimulated control, $p<0.05$, ANOVA). However, mutation of the AP-1 site substantially reduced basal promoter activity, demonstrating this region to be a basal level enhancer.

\section{DISCUSSION}

We have shown that 1) tracheal aspirates from mechanically ventilated premature infants with respiratory disease contain ample amounts of IL- 8 protein, as well as modest levels of IL- $1 \alpha$, IL- $1 \beta$, and TNF- $\alpha$; 2) tracheal aspirates induce IL-8 promoter activity and protein expression in human bronchial epithelial cells, whereas aspirates from full-term newborn infants have no significant effect on IL-8 promoter activity; 3) neutralizing antibody against IL- $1 \beta$, but not IL- $1 \alpha$ or TNF- $\alpha$, significantly attenuates tracheal aspirate-induced IL-8 protein expression; 4) tracheal aspirates induce NF- $\kappa \mathrm{B}$ DNA binding activity; 5) tracheal aspirates and IL- $1 \beta$ induce NF- $\kappa \mathrm{B}$ transactivation; and 6 ) the IL- 8 promoter NF- $\kappa \mathrm{B}$ site is required for tracheal aspirate-induced IL-8 transcription. Together, these results suggest that airway fluid from mechanically ventilated premature infants contains factor(s) that are capable of inducing airway epithelial cell IL-8 expression via an NF- $\kappa \mathrm{B}-$ dependent pathway, and that IL- $1 \beta$ appears to play a significant role in this process.

Recent evidence suggests the importance of inflammation in the pathogenesis of BPD. During the first days of postnatal life, an influx of polymorphonuclear leukocytes and macrophages is seen in the tracheal aspirates of mechanically ventilated premature infants who later develop BPD (1). Elevations of pro-inflammatory cytokines such as IL-8, IL-6, IL-1 $\beta$, and TNF- $\alpha$ are also seen (3-7). Of the cytokines implicated in BPD, IL-8 may be of special importance, as it is the most potent neutrophil chemotactic factor. We found that tracheal aspirates from mechanically ventilated premature infants induced IL-8 promoter activity and protein expression in human bronchial epithelial cells. Although the difficulty of obtaining tracheal aspirates prevented us from making comprehensive measurements of lung fluid from full-term infants without lung disease, limited studies showed no significant effect on IL-8 promoter activity. In a study of chronic lung disease in premature baboons, Coalson and colleagues (8) found that increased tracheal aspirate IL-8 and neutrophils preceded morphometric changes consistent with human chronic lung disease of prematurity. In addition, Deng et al. (9) found that antibodies against rat neutrophil chemokines analogous to IL-8 attenuate hyperoxia-induced inflammatory cellular influx, septal thickening, and mortality in these animals. Together, these data suggest that IL-8 plays a significant role in the pathogenesis of chronic lung disease in premature infants. Accordingly, we speculate that blockade of IL-1 $\beta$ signaling might attenuate airway inflammation in premature infants undergoing mechanical ventilation, thereby decreasing the incidence or severity of BPD.

Based on transcription from the IL-8 promoter, we conclude that tracheal aspirate-induced IL-8 expression in the airway epithelium is transcriptionally regulated. Other mechanisms for the regulation of IL-8 protein abundance, for example, the regulation of IL-8 translation, mRNA half-life, or protein degradation may also exist $(27,28)$.

We confirmed that IL-8, IL- $1 \alpha$, IL- $1 \beta$, and TNF- $\alpha$ are present in the tracheal aspirates of premature infants undergoing mechanical ventilation. The amounts of IL- $8, \mathrm{IL}-1 \beta$, and TNF- $\alpha$ we observed were within the broad range of values 
previously reported (2-7). We also found that concentrations of IL- $1 \beta$ and IL- $1 \alpha$ adequate to induce airway epithelial cell IL-8 expression are present in tracheal aspirates of mechanically ventilated premature infants within the first $2 \mathrm{wk}$ of life. Further, we found that neutralizing antibody to IL- $1 \beta$, but not IL- $1 \alpha$ or TNF- $\alpha$, significantly attenuated tracheal aspirateinduced IL- 8 protein abundance. In a recent study examining IL-8 expression in the lung tissue of neonates with hyaline membrane disease, the majority of cases demonstrated IL-8 immunoreactivity in fetal and neonatal neutrophils, and in almost half of these cases, airway epithelial cell immunoreactivity (10). Alveolar IL-8 expression was also present in nearly one-quarter of the cases (10). IL-8 expression has also been observed in exfoliated epithelial cells obtained following tracheal lavage of premature infants undergoing mechanical ventilation (6). Together these findings suggest that IL-1 $\beta$ induced bronchial epithelial cell IL-8 expression may contribute to the increased IL- 8 levels observed in the airways of mechanically ventilated premature infants.

Although neutralizing antibody to IL- $1 \beta$ significantly reduced tracheal aspirate-induced IL- 8 protein abundance, a substantial amount of IL- 8 induction remained. Because the tracheal aspirates themselves included IL-8, the blocking effect of the IL- $1 \beta$ antibody may have been underestimated. On the other hand, it is conceivable that other cytokines play a role. For example, neutralizing antibody to IL- $1 \alpha$ also reduced IL- 8 expression, though the effect was not statistically significant.

We obtained data strongly suggesting that endotoxin in the tracheal aspirates was not responsible for the observed IL-8 expression. Endotoxin has been demonstrated to increase airway epithelial cell IL-8 expression cells $(25,26)$. In the latter studies, LPS concentrations of $10-100 \mu \mathrm{g} / \mathrm{mL}$ were used. We found endotoxin concentrations of tracheal aspirates to be much lower, on average $2.33 \mathrm{EU} / \mathrm{mL}$, equivalent to $0.23 \mathrm{ng} / \mathrm{mL}$ LPS. Finally, overnight incubation of cells with concentrations of LPS up to $1 \mu \mathrm{g} / \mathrm{mL}$ failed to increase IL-8 promoter activity. On the other hand, we cannot rule out the possibility that bacterial colonization contributes to IL-8 induction in vivo.

The basic NF- $\kappa \mathrm{B}$ complex is a dimer of two members of the Rel family of proteins, p50 (NF- $\kappa \mathrm{B} 1)$ and p65 (Rel A). In unstimulated cells, NF- $\kappa \mathrm{B}$ is sequestered in the cytoplasm by $\mathrm{I}-\kappa \mathrm{B}$ family proteins. I- $\kappa \mathrm{B}$ phosphorylation, with subsequent polyubiquitination, allows unmasking of the $\mathrm{NF}-\kappa \mathrm{B}$ nuclear localization sequence, leading to its translocation to the nucleus, where it may regulate gene transcription. In our study, incubation of tracheal aspirates from mechanically ventilated premature infants with cultured bronchial epithelial cells induced the binding of nuclear proteins to NF- $\kappa \mathrm{B}$ oligonucleotide binding sequences. Both tracheal aspirates and IL- $1 \beta$ induced transactivation of an NF- $\kappa \mathrm{B}$ reporter plasmid. We also identified the presence of p65 RelA in the DNA binding complex. Mutation of the IL- 8 promoter NF- $\kappa \mathrm{B}$ site abolished tracheal aspirate-induced IL-8 transcription. Although basal and tracheal aspirate-induced IL- 8 promoter activities were reduced after mutation of the AP- 1 site, responsiveness to the tracheal aspirates was maintained. Together, these data demonstrate the importance of the IL- 8 promoter NF- $\kappa \mathrm{B}$ site for tracheal aspirate-induced IL- 8 transcription, and the role of the AP-1 site as a basal level enhancer.

It should be noted that the content of tracheal aspirates from premature infants may not reflect the airway liquid from distal airways. Nonetheless, a comparison of tracheal aspiration and nonbronchoscopic lung lavage in ventilated infants with lung disease demonstrated that, although bronchoalveolar lavage has more distal origin, analysis of tracheal aspirate fluid may have equal validity in the estimation of indices of pulmonary surfactant (29). Also, we did not normalize tracheal aspirates for dilution. Although various groups have used such indices as urea, albumin, and total protein for this purpose, the concentrations of these molecules may be altered by such factors as dwell time and capillary permeability. A recent European Respiratory Society task force on the use of bronchoalveolar lavage for research in children concluded there are no reliable dilution factors in tracheal aspirates from children, and did not recommend correcting results for dilution (30). Finally, we did not study human airway epithelial cells from premature infants. Nevertheless, we consider the human bronchial epithelial cell line we used to be an adequate indicator of human bronchial epithelial cell response to the cytokine milieu present in tracheal aspirates.

We have established a useful system for determining the functional relevance of various factors that may be found in the aspirates, and for examining the biologic effects of therapeutic interventions on airway inflammation in these infants. Future clinical studies could assess the effects of anti-inflammatory therapy and blockade of IL- $1 \beta$ signaling on airway epithelial cell cytokine elaboration.

Acknowledgments. The authors thank Dr. Steven White for his gift of the 16HBE14o- bronchial epithelial cells, Dr. Marsha Rosner for her gift of pCMV-LacZ, and the University of Chicago Children's Hospital Neonatal Intensive Care Unit nurses for their assistance in collecting patient samples.

\section{REFERENCES}

1. Merritt TA, Stuard ID, Puccia J, Wood B, Edwards DK, Finkelstein J, Shapiro DL 1981 Newborn tracheal aspirate cytology: classification during respiratory distress syndrome and bronchopulmonary dysplasia. J Pediatr 98:949-956

2. Bagchi A, Viscardi RM, Taciak V, Ensor JE, McCrea KA, Hasday JD 1994 Increased activity of interleukin- 6 but not tumor necrosis factor-alpha in lung lavage of premature infants is associated with the development of bronchopulmonary dysplasia. Pediatr Res 36:244-252

3. Jones CA, Cayabyab RG, Kwong KY, Stotts C, Wong B, Hamdan H, Minoo P, deLemos RA 1996 Undetectable interleukin (IL)-10 and persistent IL-8 expression early in hyaline membrane disease: a developmental basis for predisposition to chronic lung inflammation in preterm newborns. Pediatr Res 39:966-975

4. Ozdemir A, Brown MA, Morgan WJ 1997 Markers and mediators of inflammation in neonatal lung disease. Pediatr Pulmonol 23:292-306

5. Tullus K, Noack GW, Burman LG, Nilsson R, Wretlind B, Brauner A 1996 Elevated cytokine levels in tracheobronchial aspirate fluids from ventilator treated neonates with bronchopulmonary dysplasia. Eur J Pediatr 155:112-116

6. Kotecha S, Wilson L, Wangoo A, Silverman M, Shaw JR 1996 Increase in interleukin (IL)- $1 \beta$ and IL-6 in bronchoalveolar lavage fluid obtained from infants with chronic lung disease of prematurity. Pediatr Res 40:250-256

7. Kotecha S, Chan B, Azam N, Silverman M, Shaw RJ 1995 Increase in interleukin-8 and soluble intercellular adhesion molecule-1 in bronchoalveolar lavage fluid from premature infants who develop chronic lung disease. Arch Dis Child 72:F90-F96

8. Coalson JJ, Winter VT, Siler-Khodr T, Yoder BA 1999 Neonatal chronic lung disease in extremely immature baboons. Am J Resp Crit Care Med 160:1333-1346

9. Deng H, Mason N, Auten RL 2000 Lung inflammation in hyperoxia can be prevented by antichemokine treatment in newborn rats. Am J Respir Crit Care Med 162:23162323 
10. Gahler A, Stallmach T, Schwaller J, Fey MF, Tobler A 2000 Interleukin-8 expression by fetal and neonatal pulmonary cells in hyaline membrane disease and amniotic infection. Pediatr Res 48:299-303

11. Garofalo R, Sabry M, Jamaluddin M, Yu RK, Casola A, Ogra PL, Brasier AR 1996 Transcriptional activation of the interleukin- 8 gene by respiratory syncytial virus infection in alveolar epithelial cells: nuclear translocation of the RelA transcription factor as a mechanism producing airway mucosal inflammation. J Virol 70:87738781

12. Johnston SL, Papi A, Bates PJ, Mastronarde JG, Monick MM, Hunninghake GW 1998 Low grade rhinovirus infection induces a prolonged release of IL-8 in pulmonary epithelium. J Immunol 160:6172-6181

13. Mio T, Romberger DJ, Thompson AB, Robbins RA, Heires A, Rennard SI 1997 Cigarette smoke induces interleukin-8 release from human bronchial epithelial cells. Am J Respir Crit Care Med 155:1770-1776

14. Chang MM, Wu R, Plopper CG, Hyde DM 1998 IL-8 is one of the major chemokines produced by monkey airway epithelium after ozone-induced injury. Am J Physiol 275:L524-L532

15. Singhal KK, Parton LA 1996 Plasminogen activator activity in preterm infants with respiratory distress syndrome: relationship to the development of bronchopulmonary dysplasia. Pediatr Res 39:229-235

16. Li J, Kartha S, Tan A, Iasvovskaia S, Bhat RK, Manaligod JM, Page K, Brasier AR, Hershenson MB 2002 Regulation of human airway epithelial cell interleukin-8 expression by mitogen-activated protein kinases. Am J Physiol Lung Cell Mo Physiol 283:L690-L699

17. Cozens A, Yezzi M, Kunzelmann K, Ohrui T, Chin L, Eng K, Finkbeiner W, Widdicomb J, Gruenert D 1994 CFTR expression and chloride secretion in polarized immortal human bronchial epithelial cells. Am J Respir Cell Mol Biol 10:38-47

18. Dorscheid DR, Conforti AE, Hamann KJ, Rabe KF, White SR 1999 Characterization of cell surface lectin-binding patterns of human airway epithelium. Histochem J 31:145-151

19. White SR, Dorscheid DR, Rabe KF, Wojcik KR, Hamann KJ 1999 Role of very late adhesion integrins in mediating repair of human airway epithelial cell monolayers after mechanical injury. Am J Respir Cell Mol Biol 20:787-796

20. Ramakrishnan M, Musa N, Li J, Liu P, Pestell R, Hershenson M 1998 Catalytic activation of extracellular signal-regulated kinases induces cyclin D1 expression in primary tracheal myocytes. Am J Respir Cell Mol Biol 18:736-740
21. Brasier AR, Jamaluddin M, Casola A, Duan W, Shen Q, Garofalo RP 1998 A promoter recruitment mechanism for tumor necrosis factor-alpha-induced interleukin-8 transcription in type II pulmonary epithelial cells. Dependence on nuclear abundance of Rel A, NF-kappaB1, and c-Rel transcription factors. J Biol Chem 273:3551-3556

22. Parmacek MS, Vora AJ, Shen T, Barr E, Jung F, Leiden JM 1992 Identification and characterization of a cardiac-specific transcriptional regulatory element in the slow cardiac tropinin C gene. Mol Cell Biol 12:1967-1976

23. Dignam JD, Lebovitz RM, Roeder RG 1983 Accurate transcription initiation by RNA polymerase II in a soluble extract from isolated mammalian nuclei. Nucleic Acids Res 11:1475-1489

24. Musa NL, Ramakrishnan M, Li J, Liu P, Pestell RG, Hershenson MB 1999 Forskolin inhibits cyclin D1 expression in airway smooth muscle. Am J Respir Cell Mol Biol 20:352-358

25. Khair OA, Devalia JL, Abdelaziz MM, Sapsford RJ, Tarraf H, Davies RJ 1994 Effect of Haemophilus influenzae endotoxin on the synthesis of IL-6, IL- 8, TNF-alpha and expression of ICAM-1 in cultured human bronchial epithelial cells. Eur Respir J 7:2109-2116

26. Palmberg L, Larsson BM, Malmberg P, Larsson K 1998 Induction of IL-8 production in human alveolar macrophages and human bronchial epithelial cells in vitro by swine dust. Thorax 53:260-264

27. Roger T, Out T, Mukaida N, Matsushima K, Jansen H, Lutter R 1998 Enhanced AP-1 and NF-kappaB activities and stability of interleukin 8 (IL-8) transcripts are implicated in IL-8 mRNA superinduction in lung epithelial H292 cells. Biochem J 330:429-435

28. Holtmann H, Winzen R, Holland P, Eickemeier S, Hoffmann E, Wallach D, Malinin NL, Cooper JA, Resch K, Kracht M 1999 Induction of interleukin-8 synthesis integrates effects on transcription and mRNA degradation from at least three different cytokine- or stress-activated signal transduction pathways. Mol Cell Biol 19:6742-6753

29. Dargaville PA, South M, McDougall PN 1999 Comparison of two methods of diagnostic lung lavage in ventilated infants with lung disease. Am J Respir Crit Care Med 160:771-777

30. de Blic J, Midulla F, Barbato A, Clement A, Dab I, Eber E, Green C, Grigg J, Kotecha S, Kurland G, Pohunek P, Ratjen F, Rossi G 2000 Bronchoalveolar lavage in children. ERS task force on bronchoalveolar lavage in children. European Respiratory Society. Eur Respir J 15:217-231 